\title{
Polyoxide Catalysts for Oxidation of Methane
}

\author{
K. Dossumov, D. Kh. Churina, G. Y. Yergaziyeva, L. K. Myltykbayeva, and E. Zh. Ermeshev
}

\begin{abstract}
The effect of modifying additives of copper, neodymium and molybdenum on acidity and dispersity of nickel catalyst was studied by temperature-programmed desorption of ammonia and scanning electron microscopy methods. Their activity in the reaction of partial oxidation of methane (POM) and dry reforming of methane (DRM) were measured. The $\mathrm{NiCuNdMo} / \mathrm{Al}_{2} \mathrm{O}_{3} \mathrm{HZSM}-5$ was found to be the best catalyst. The introduction of molybdenum into the composition of $\mathrm{NiCuNd} / \mathrm{Al}_{2} \mathrm{O}_{3} \mathrm{HZSM}-5$ catalyst was determined to increase general acidity of the catalyst from $26.71 \cdot 10^{-4}$ to $29.46 \cdot 10^{-4} \mathrm{~mol} /$ gKt, and also it increases the dispersion of the active phases of the catalysts surface. This data of change positively affects the activity of the catalyst in POM reaction, concentration of hydrogen in the reaction product compared with $\mathrm{NiCuNd} /$ $\mathrm{Al}_{2} \mathrm{O}_{3} \mathrm{HZSM}-5$ increases from 60 to 70 vol. \%. The investigation of the catalytic activity of $\mathrm{NiCuNdMo} / \mathrm{Al}_{2} \mathrm{O}_{3} \mathrm{HZSM}-5$ catalyst in the reaction of DRM has shown that equilibrium yield of $\mathrm{H}_{2}$ and $\mathrm{CO}$ is observed in the temperature range of $650-900{ }^{\circ} \mathrm{C}$. The main product in the process of oxidative conversion of methane by oxygen is hydrogen, whereas in the process of oxidative conversion of methane by carbon dioxide synthesis gas is formed
\end{abstract}

Index Terms - Nickel-containing catalyst, methane, oxygen, carbon dioxide, hydrogen.

\section{INTRODUCTION}

Natural gas is the most abundant source for obtaining energy and new chemical compounds: synthesis-gas, hydrogen, alkenes etc.

Synthesis-gas is the source for preparing of oxygenates (methanol, dimethyl ether etc.), and also for preparing liquid and solid hydrocarbons using the Fischer-Tropsch method [1]-[5]. Hydrogen, which is included in the composition of synthesis-gas, finds an application in a number of large-scale chemical processes (ammonia production, hydrorafination of fuels, hydrocracking of oil sources, isomerization of $\mathrm{n}$-alkanes etc.). At the same time hydrogen may find the wide application as an alternative motor fuel in the future [6]-[11].

There are several methods of catalytic processing of methane to synthesis-gas and hydrogen - steam reforming, partial oxidation and dry reforming of methane.

Steam reforming is the main industrial process of preparing synthesis-gas and hydrogen from methane on nickel-containing catalysts. The disadvantage of this method

Manuscript received April 10, 2015; revised May 25, 2015. This manuscript was supported in part by Ministry of Education and Science of the Republic of Kazakhstan.

K. Dossumov and D. Churina are with The Center of Physical-chemical Methods of Investigations and Analysis of Al-Farabi Kazakh National University, Almaty, Kazakhstan (e-mail: dossumov50@mail.ru, dina.churina@gmail.com).

G. Yergaziyeva is with The Institute of Combustion Problems MES RK, Almaty, Kazakhstan (e-mail: ergazieva_g@mail.ru).

L. K. Myltykbayeva and E. Zh. Ermeshev are with Al-Farabi Kazakh National University, Almaty, Kazakhstan (e-mail: laura.kaden@mail.ru). is the high ratio of $\mathrm{H}_{2}: \mathrm{CO}$ in the prepared mixture, which is not suitable Fischer-Tropsch synthesis to be obtain dimethyl ether, methanol. The other disadvantage of using this method is that a large amount of $\mathrm{CO}_{2}$ is formed in the mixture and coke formation on the catalysts [12]-[16].

Partial oxidation of methane (POM) into synthesis-gas is widely studied both concerning the development of catalysts, and the technology of process. At present there are developed efficient catalysts based on noble metals, and also $\mathrm{Ni}$, Co perovskites, containing REE (rare earth elements), promoted by $\mathrm{Pt}, \mathrm{Fe}, \mathrm{Cu}$ [17]-[23]. Although desirable ratio $\mathrm{H}_{2} / \mathrm{CO}(1: 1)$ can be obtained using the method of POM, this process requires special measures of precaution because of the danger of explosion, and also it is being tested at the laboratory at this moment.

Dry reforming of methane solves the problem of utilization of simultaneously two greenhouse gases methane and carbon dioxide in synthesis-gas [24]-[27]. DRM leads to the preparation of synthesis gas $\left(\mathrm{H}_{2} / \mathrm{CO}\right)$ of composition 1:1, which is convenient, in particular, for the preparation of polycarbonates or formaldehyde. Also application of DRM has been proved in cases, where there is a necessity in processing of the natural gas containing carbon dioxide. Such of a low grade natural gas requires the separation to make it a commercial product, at the same time carbon dioxide which is a pollutant in this case can be used as a reagent for the conversion of natural gas. The process of DRM has not found yet a wide distribution in industry, as the main problem is the coke formation of catalyst. The main efforts in this field are directed towards the development of the stable catalysts maintaining coke formation [28].

In present work the nickel-containing catalysts are studied in the processes of the oxidation of methane by oxygen and carbon dioxide.

\section{EXPERIMENTAL}

Experiments to test the efficiency of the catalysts in the process of POM and DRM were carried out using an automated flow catalytic setup (FCS - 1). The setup was composed of three main parts - preparation of initial gaseous mixture, catalytic quartz reactor of a flow type and chromatographer for the analysis of gases (Fig. 1). The reactor was a quartz tube of $25 \mathrm{~cm}$ in length, and its internal diameter was 9-9.5 $\mathrm{mm}$. During the experiments, the reactor was vertically placed in an electric furnace, and the reactant mixture was supplied to the reactor from the top. After the reactant was passed through the catalyst bed, the converted gas left the reactor through a hole in the lower part of the reactor. Control of the composition and the expense of initial reacting mixtures, regulation of temperatures in the reactor, evaporator, and start of analysis were carried out using the 
software. The amounts of the reaction products were determined by an absolute calibration method using a gas chromatograph equipped with a thermal conductivity detector (HROMOS GH-1000). The separation of each component in a product was carried out by three columns with a (length of 2 $\mathrm{m}$, internal diameter of $3 \mathrm{~mm})$ filled with zeolite $\mathrm{NaX}(2$ columns) and porapack-T, using argon as the carrier gas.

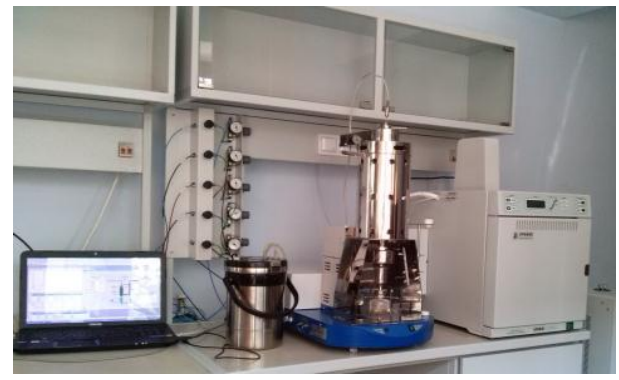

Fig. 1. Flow catalytic setup.

Conditions of the processes were $0.1 \mathrm{MPa}$, the temperature range used by us was $650-900{ }^{\circ} \mathrm{C}$, ratio of methane: oxygen $2: 1$, ratio of methane : carbon dioxide was varied within the limits of 0.25-4.

The study of the morphology of the surface of polyoxide catalysts was carried out by scanning electron microscopy method using a scanning electronic microscope (Quanta 200i $3 \mathrm{D})$. The formation of acidic centers on the surface of the catalysts was determined by thermoprogrammed desorption of ammonia method using a universal sorption gas analyzer (USGA -101).

The catalysts were prepared by the impregnation of $\mathrm{Al}_{2} \mathrm{O}_{3}$ HZSM-5 $\left(\mathrm{S}_{\mathrm{BET}}=308.6 \mathrm{~m}^{2} / \mathrm{g}\right)$ with a solutions of $\mathrm{Ni}\left(\mathrm{NO}_{3}\right)_{2} \bullet 6 \mathrm{H}_{2} \mathrm{O}, \quad \mathrm{Cu}\left(\mathrm{NO}_{3}\right)_{2} \bullet 3 \mathrm{H}_{2} \mathrm{O}, \quad \mathrm{Nd}\left(\mathrm{NO}_{3}\right)_{3} \bullet 6 \mathrm{H}_{2} \mathrm{O}$ and $\left(\mathrm{NH}_{4}\right)_{6} \mathrm{Mo}_{7} \mathrm{O}_{24} \bullet 4 \mathrm{H}_{2} \mathrm{O}$, drying at $350{ }^{\circ} \mathrm{C}$ (for 2 hours), and then calcination at $500{ }^{\circ} \mathrm{C}$ for three hours.

\section{RESULTS AND DISCUSSION}

In the process of the oxidation of methane by oxygen the activities of the series of nickel-containing catalysts supported on various carriers $\left(\mathrm{Al}_{2} \mathrm{O}_{3} \mathrm{ZSM}-5\right.$, Siral-40, $\mathrm{CaX}, \mathrm{Al}_{2} \mathrm{O}_{3}$, Siral-20, Siral-10 and AlSi) were studied in temperatures range of $600-900^{\circ} \mathrm{C}$. Obtained results are shown, that according to the yield of products the catalyst supported on $\mathrm{Al}_{2} \mathrm{O}_{3} \mathrm{HZSM}-5$ synthetic zeolite is the optimal.

TABLE I: EFFECT OF CATALYST COMPOSITION ON THE CONCENTRATION OF PRODUCTS

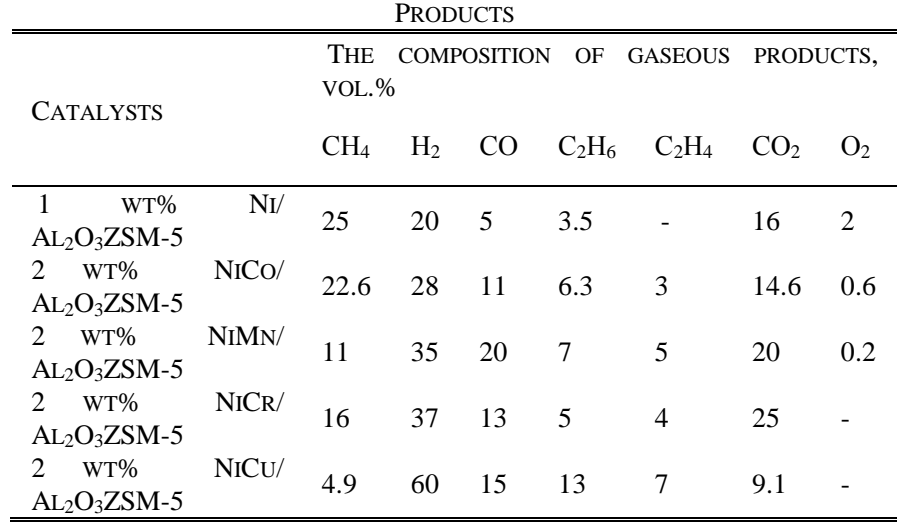

The effect of the oxides of variable valence $(\mathrm{Mn}, \mathrm{Co}, \mathrm{Cu}$ and $\mathrm{Cr}$ ) on activity of $\mathrm{Ni} / \mathrm{Al}_{2} \mathrm{O}_{3} \mathrm{ZSM}-5$ catalyst is studied. The results are shown in Table I.

Prepared catalysts were tested in oxidative transformation of methane at $\mathrm{CH}_{4}: \mathrm{O}_{2}=2.0: 1 ., \mathrm{V}=3900 \mathrm{~h}^{-1}$. Table I shows, that the most optimal composition for two-component catalyst is the $\mathrm{NiCu}$, the concentration of hydrogen in the reaction products is $60 \mathrm{vol} . \%$. According to the literature data addition of rare-earth elements increases selectivity and activity of oxide catalysts in the process of POM [29].

The most optimal composition of $\mathrm{NiCu} / \mathrm{Al}_{2} \mathrm{O}_{3} \mathrm{ZSM}-5$ catalyst was modified by adding the salts of rare-earth elements - Ce, La, Nd and Sm. Obtained results were shown in Table II. Promoting effect is produced by the addition of neodymium, where the concentration in reaction products of hydrogen increases to 68 vol. $\%$.

TABLE II: INFLUENCE OF THE ADDITIVES OF RARE EARTH ELEMENTS ON CONCENTRATION OF PRODUCTS

\begin{tabular}{|c|c|c|c|c|c|c|c|}
\hline \multirow[t]{2}{*}{ CATALYSTS } & \multicolumn{3}{|c|}{$\begin{array}{l}\text { THE COMPOSITION } \\
\text { VOL. } \%\end{array}$} & OF & GASEOUS & \multicolumn{2}{|c|}{ PRODUCTS, } \\
\hline & $\mathrm{CH}_{4}$ & $\mathrm{H}_{2}$ & $\mathrm{CO}$ & $\mathrm{C}_{2} \mathrm{H}_{6}$ & $\mathrm{C}_{2} \mathrm{H}_{4}$ & $\mathrm{CO}_{2}$ & $\mathrm{O}_{2}$ \\
\hline $\begin{array}{l}3 \text { wT\% NICULA/ } \\
\mathrm{AL}_{2} \mathrm{O}_{3} \mathrm{ZSM}-5\end{array}$ & 9 & 53 & 15 & 6 & 7 & 12 & - \\
\hline $\begin{array}{l}3 \mathrm{WT} \% \text { NiCuSM/ } \\
\mathrm{AL}_{2} \mathrm{O}_{3} \mathrm{ZSM}-5\end{array}$ & 25 & 27 & 14 & 9 & 4 & 20 & 0.3 \\
\hline $\begin{array}{l}3 \mathrm{WT} \% \text { NICUCE/ } \\
\mathrm{AL}_{2} \mathrm{O}_{3} \mathrm{ZSM}-5\end{array}$ & 16 & 48 & 12 & 11 & 5 & 8 & - \\
\hline $\begin{array}{l}3 \mathrm{WT} \% \text { NICUND/ } \\
\mathrm{AL}_{2} \mathrm{O}_{3} \mathrm{ZSM}-5\end{array}$ & 2 & 68 & 18 & - & 10 & 2 & - \\
\hline
\end{tabular}

According to the literature data [30], [31], the activity of catalyst increases with the increase of the number of acidic centers of the catalyst. We have found out that the increase of the complexity of the composition of three-component catalyst by the addition of the $\mathrm{W}$ and Mo oxides of the acidic characters, leads to the increase of hydrogen to 69 vol. \% in case of tungsten. When adding molybdenum to the composition of $\mathrm{NiCuNd} / \mathrm{Al}_{2} \mathrm{O}_{3} \mathrm{HZSM}-5$ the catalyst the concentration of hydrogen in the reaction products increases to 70 vol. $\%$.

Thus, among the studied nickel-containing catalysts the highest activity exhibits in the process of oxidative conversion of methane in the presence of oxygen by $\mathrm{NiCuNd} / \mathrm{Al}_{2} \mathrm{O}_{3} \mathrm{HZSM}-5$ catalyst.

Dry reforming of methane is studied on NiCuNdMo $/ \mathrm{Al}_{2} \mathrm{O}_{3} \mathrm{HZSM}-5$ catalyst. The effect of the temperature of reaction on the activity of the catalyst is studied in the temperature range of $600-900^{\circ} \mathrm{C}$ at volume rate of $3600 \mathrm{~h}^{-1}$ and ratio of $\mathrm{CH}_{4} / \mathrm{CO}_{2}$ - 2 (Fig. 2). As shows figure, with the increase of the temperature of the process of DRM from 600 to $900{ }^{\circ} \mathrm{C}$ the conversion of methane increases from $4 \%$ to $78 \%$ and the conversion of carbon dioxide increases from 5 to $98 \%$. At $600{ }^{\circ} \mathrm{C}$ in the reaction products concentration of $\mathrm{H}_{2}(1.6$ vol. \%) and $\mathrm{CO}(6.9$ vol.\%) is observed. With increasing the process temperature from 600 to $900{ }^{\circ} \mathrm{C}$ the concentration of hydrogen increase to 49.8 vol.\% and carbon monoxide to 45.0 vol.\% in the reaction products. The obtained experimental data show, that there is observed the equilibrium yield of $\mathrm{H}_{2}$ and $\mathrm{CO}$ on this catalyst 
in the whole temperature range, similar data were obtained in work [32] on the $\mathrm{Ni} / \mathrm{Al}_{2} \mathrm{O}_{3}$ catalyst. The Fig. 2 shows that at $\mathrm{T}$ $=850{ }^{\circ} \mathrm{C}$ the concentrations of hydrogen and carbon monoxide become stable and reach a plateau, related to this study, so effect of ratio $\mathrm{CH}_{4} / \mathrm{CO}_{2}$ within the range from 0.5 to 4 on the activity of catalyst was studied at the given temperature. The results of the effects of the ratio of $\mathrm{CH}_{4} / \mathrm{CO}_{2}$ on the activity of $\mathrm{NiCuNdMo} / \mathrm{Al}_{2} \mathrm{O}_{3} \mathrm{HZSM}-5$ are shown in Fig. 3.

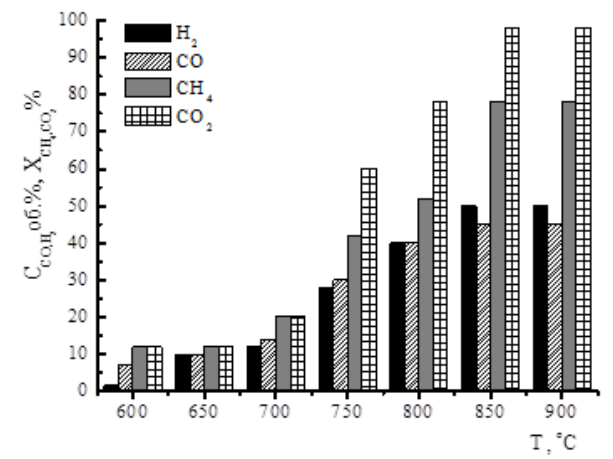

Fig. 2. Effect of the reaction temperature on the conversion of $\mathrm{CH}_{4}$ and $\mathrm{CO}_{2}$ and concentration of main products.

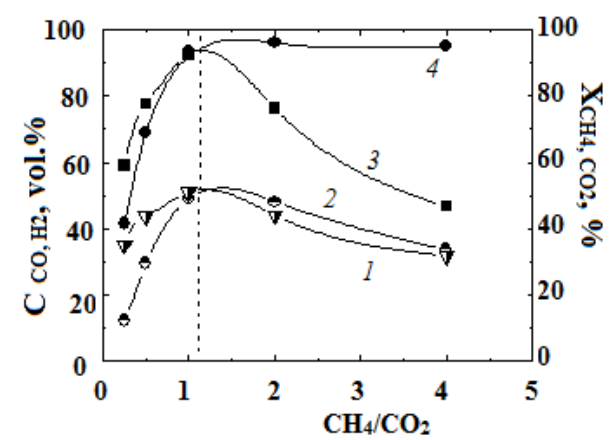

$1-\mathrm{CO} ; 2-\mathrm{H}_{2} ; 3-\mathrm{CH}_{4} ; 4-\mathrm{CO}_{2}$

Fig. 3. Effect of ratio of $\mathrm{CH}_{4} / \mathrm{CO}_{2}$ on the activity of catalyst at $850^{\circ} \mathrm{C}$.

The figure shows, that the dependence of the conversion of methane on the ratio of $\mathrm{CH}_{4} / \mathrm{CO}_{2}$ has an extremal character with the maximum located in the region close to 1 and corresponds to $92.6 \%$. The curves of the target products of the reaction of hydrogen and carbon monoxide also possess maximal values $\left(\mathrm{H}_{2}-49\right.$ vol. $\%$ and $\mathrm{CO}-50$ vol. \%) at the ration of $\mathrm{CH}_{4} / \mathrm{CO}_{2}$ close to 1 . Increase of the value of the ratio leads to sufficiently rapid decreasing of methane conversion. In contrast to methane, conversion of carbon dioxide at the ratio close to 1 reaches $92.3 \%$ with a further reaching of the plateau values of the order of $96 \%$. According to [33] carbon dioxide interact with hydrogen which is spent on formation of water and carbon.

One may state, that the most optimal ratio for the process of DRM is the stoichiometric ratio, under which the maximal concentration of synthesis gas and the highest conversion of initial reagents are achieved.

The effect of volume rate on the process of DRM is studied in the range of from 1800 to $14400 \mathrm{~h}^{-1}$. Obtained results (Fig. 4) show, that, with increasing volume rate from 1800 to 3600 $\mathrm{h}^{-1}$ both the conversion and the yields of reaction products are at the similar level.

Thus, the most optimal technological parameters of the preparation of synthesis gas in the process of DRM on $\mathrm{NiCuNdMo} / \mathrm{Al}_{2} \mathrm{O}_{3} \mathrm{HZSM}-5$ catalyst are: temperature $-850{ }^{\circ} \mathrm{C}$, volume rate $-3600 \mathrm{~h}^{-1}$ and ratio $\mathrm{CH}_{4}: \mathrm{CO}_{2}-1: 1$.

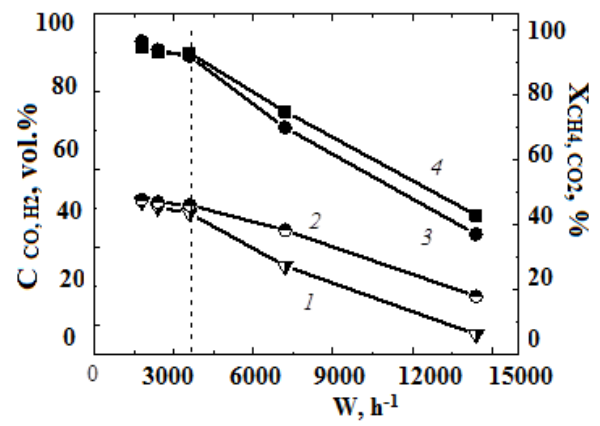

$1-\mathrm{H}_{2} ; 2-\mathrm{CO} ; 3-\mathrm{CH}_{4} ; 4-\mathrm{CO}_{2}$

Fig. 4. Effect of volume rate on the activity of catalyst.

It should be noted, that in the process of oxidative conversion of methane by oxygen the main product is the hydrogen, while in the process of dry reforming of methane the synthesis gas is formed.

For the disclosure of the reason of activity of modified catalysts they were studied with the application of the methods of scanning electronic microscopy (SEM) and thermoprogrammed desorption of ammonia (TPD).

The morphology of the surface of the catalysts depending on the introduction of modified additives was studied using the method of scanning electronic microscopy, obtained results are shown in Fig. 5.

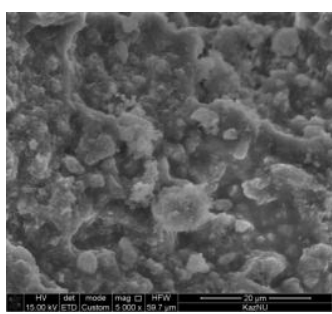

a) $\mathrm{Al}_{2} \mathrm{O}_{3} \mathrm{HZSM}-5$

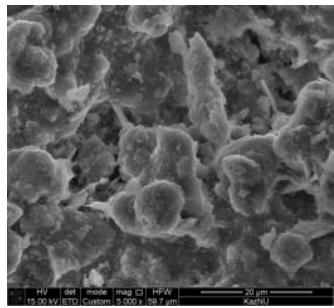

c) $\mathrm{NiCuNd} / \mathrm{Al}_{2} \mathrm{O}_{3} \mathrm{HZSM}-5$

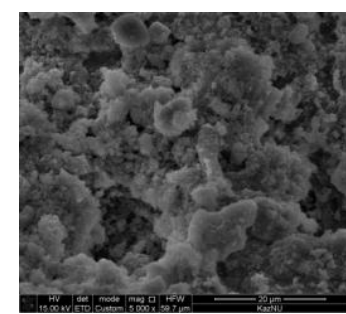

b) $\mathrm{NiCu} / \mathrm{Al}_{2} \mathrm{O}_{3} \mathrm{HZSM}-5$

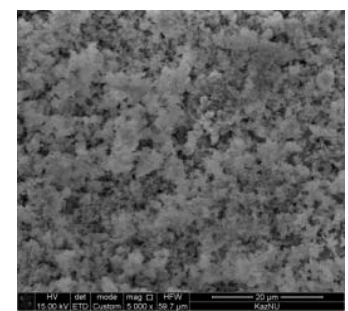

d) $\mathrm{NiCuNdMo} / \mathrm{Al}_{2} \mathrm{O}_{3} \mathrm{HZSM}-5$
Fig. 5. Microphotographs of catalysts.

Fig. 5 shows that the increase of the complexity of the composition of polyoxide catalyst leads to the increase of the dispersion of active phases of the surface, which positively affects the catalytic activity of catalysts.

Formation of acidic centers on the surface of catalysts was studied using the thermoprogrammed desorption of ammonia (TPD), obtained data are shown in Table III. According to the obtained data in Table III shows that ammonia desorption from the catalysts surface proceeds at three temperature ranges on all catalysts. Within the temperature range of $50-200^{\circ} \mathrm{C}$ ammonia is desorbed from the centers of an average 
strength, from strong acidic centers - higher than $300^{\circ} \mathrm{C}$, which correspondens to the data of works [34], [35]. With increasing composition of the catalyst (NiCuNdMo $\left./ \mathrm{Al}_{2} \mathrm{O}_{3} \mathrm{ZSM}-5\right)$ the amount of the catalyst desorbed from average strength acidic centers increases from $6.32 \cdot 10^{-4}$ to $9.78 \cdot 10^{-4}$ compared to $\mathrm{Ni} / \mathrm{Al}_{2} \mathrm{O}_{3} \mathrm{ZSM}-5$, and the amount of ammonia desorbed from weak acidic centers from $7.22 \cdot 10^{-4}$ to $14.87 \cdot 10^{-4} \mathrm{~mol} / \mathrm{g}$ Cat increases too.

TABLE III: RESULTS OF THERMO-PROGRAMMED DESORPTION OF AMMONIA FROM CATALYSTS

\begin{tabular}{llll}
\hline \hline Sample & Tmax, ${ }^{\circ} \mathrm{C}$ & \multicolumn{2}{c}{ Amount of adsorbed ammonia } \\
mol/g Cat & $\begin{array}{c}\text { total amount } \\
\text { mol/g Cat }\end{array}$ \\
\hline $1 \mathrm{wt} \% \mathrm{Ni} /$ & 130 & $7.22 \cdot 10^{-4}$ & $18.09 \cdot 10^{-4}$ \\
$\mathrm{Al}_{2} \mathrm{O}_{3} \mathrm{ZSM}-5$ & 230 & $6.32 \cdot 10^{-4}$ & \\
& 620 & $4.55 \cdot 10^{-4}$ & \\
$2 \mathrm{wt} \% \mathrm{NiCu} /$ & 160 & $9.02 \cdot 10^{-4}$ & $22.36 \cdot 10^{-4}$ \\
$\mathrm{Al}_{2} \mathrm{O}_{3} \mathrm{ZSM}-5$ & 280 & $8.13 \cdot 10^{-4}$ & \\
& 660 & $5.21 \cdot 10^{-4}$ & \\
$3 \mathrm{wt} \% \mathrm{NiCuNd} /$ & 135 & $12.35 \cdot 10^{-4}$ & $26.71 \cdot 10^{-4}$ \\
$\mathrm{Al}_{2} \mathrm{O}_{3} \mathrm{ZSM}-5$ & 275 & $8.55 \cdot 10^{-4}$ & \\
& 650 & $5.81 \cdot 10^{-4}$ & \\
$4 \mathrm{wt} \% \mathrm{NiCuNdMo} /$ & 120 & $14.87 \cdot 10^{-4}$ & $29.46 \cdot 10^{-4}$ \\
$\mathrm{Al}_{2} \mathrm{O}_{3} \mathrm{ZSM}-5$ & 250 & $9.78 \cdot 10^{-4}$ & \\
& 640 & $4.81 \cdot 10^{-4}$ & \\
\hline \hline
\end{tabular}

\section{CONCLUSION}

Thus, in the reaction of the oxidation of methane by oxygen the nickel containing catalysts supported on various carriers such as $\mathrm{Al}_{2} \mathrm{O}_{3} \mathrm{ZSM}-5$, Siral-40, $\mathrm{CaX}, \mathrm{Al}_{2} \mathrm{O}_{3}$, Siral-20, Siral-10 and AlSi were studied. The highest activity was exhibited by the catalyst $\mathrm{Ni} / \mathrm{Al}_{2} \mathrm{O}_{3} \mathrm{ZSM}-5$, while the concentration of hydrogen in the reaction products is 20 vol. $\%$. The increase of activity of $\mathrm{Ni} / \mathrm{Al}_{2} \mathrm{O}_{3} \mathrm{ZSM}-5$ catalyst was found out to be adding observed when of metal oxides of varied valency (Mn, $\mathrm{Co}, \mathrm{Cu}$ and $\mathrm{Cr}$ ). The most optimal composition is $\mathrm{NiCu}$, the concentration of hydrogen in the reaction of product is 60 vol. \%. Addition of rare-earth elements to the composition of $\mathrm{NiCu} / \mathrm{Al}_{2} \mathrm{O}_{3} \mathrm{ZSM}-5$ changes the activity of the catalyst. The highest promoting effect is shown by neodymium, the concentration of hydrogen in the reaction products increases to $68 \mathrm{vol} . \%$. The increase of complexity of composition $\mathrm{NiCuNd} / \mathrm{Al}_{2} \mathrm{O}_{3} \mathrm{HZSM}-5$ catalyst by the addition of $\mathrm{W}$ and Mo oxides of acidic character, leads to the increase of yield of hydrogen to 69 and 70 vol.\%, correspondingly.

With introducing the molybdenum into composition of $\mathrm{NiCuNd} / \mathrm{Al}_{2} \mathrm{O}_{3} \mathrm{HZSM}-5$ catalyst of hydrogen concentration in the reaction products increases from 60 to 70 vol. $\%$ which is explained by increase in acidity of the catalyst $26.71 \cdot 10^{-4}$ to $29.46 \cdot 10^{-4} \mathrm{~mol} / \mathrm{g}$ Cat and also by increases of dispersion of the active phase of the catalyst surface.

The study of the process DRM on the $\mathrm{NiCuNdMo} / \mathrm{Al}_{2} \mathrm{O}_{3} \mathrm{HZSM}-5$ catalyst has shown, that the optimal conditions of the process are the ratio $\mathrm{CH} 4: \mathrm{CO} 2-1: 1$, $\mathrm{T}-850{ }^{\circ} \mathrm{C}, \mathrm{W}-3600 \mathrm{~h}^{-1}$ while the concentration of formed hydrogen is 48.9 vol. $\%$, the concentration of carbon monoxide is 50.9 vol. $\%$, conversion of methane $-92.6 \%$ and conversion of carbon dioxide $-93.2 \%$. It was found that the equilibrium yield of $\mathrm{H}_{2}$ and $\mathrm{CO}$ is observed in the process of $\mathrm{DRM}$ in the range of temperatures from 650 to $900{ }^{\circ} \mathrm{C}$.

\section{REFERENCES}

[1] A. Tsolakis and M. L.Wyszynski, "Biogas upgrade to syn-gas $\left(\mathrm{H}_{2}-\mathrm{CO}\right)$ via dry and oxidative reforming," Int. J. Hydrogen Energy, vol. 36, pp. 397-404, 2011.

[2] T. Valliyappan, N. N. Bakhshi, and A. K. Dalai, "Pyrolysis of glycerol for the production of hydrogen or syn gas," Bioresour Technol, vol. 99, pp. 4476-4483, 2008.

[3] S. Rapagná, H. Provendier, C. Petit, A. Kiennemann, and P. U. Foscolo, "Development of biomass gasification," Biomass Bioenergy, vol. 22, pp. 377-388, 2002.

[4] R. Jens Rostrup-Nielsen, "New aspects of syngas production and use," Catal. Today, vol. 63, pp. 159-164, 2000.

[5] S. S. Bharadwaj and L. D. Schmidt, "Catalytic partial oxidation of natural gas to syngas," Fuel Proces. Technol, vol. 42, pp. 109-127, 1995.

[6] S. Freni, G. Calogero, and S. J. Cavallaro, "Hydrogen production from methane through catalytic partial oxidation reactions," Power Sources, vol. 87, pp. 28-38, 2000.

[7] D. Das and T. Nejat Veziroğlu, "Hydrogen production by biological processes: A survey of literature," Int. J. Hydrogen Energy, vol. 26, pp. 13-28, 2001.

[8] N. Meng, K. H. Michael, Y. C. Leung, D. Leung, and K. Sumathy, “A review and recent developments in photocatalytic water-splitting using $\mathrm{TiO}_{2}$ for hydrogen production," Renewable \& Sustainable Energy Reviews, vol. 11, pp. 401-425, 2007.

[9] F. R. Hawkes, R. Dinsdale, D. L. Hawkes, and I. Hussy, "Sustainable fermentative hydrogen production: challenges for process optimisation," Int. J. Hydrogen Energy, vol. 27, pp. 1339-1347, 2002.

[10] I. K. Kapdan and F. Kargi, "Bio-hydrogen production from waste materials," Enzyme Microb. Technol, vol. 38, pp. 569-582. 2006.

[11] A. F. Ghenciu, "Review of fuel processing catalysts for hydrogen production in PEM fuel cell systems," Curr. Opin. Solid State Mater. Sci., vol. 6, pp. 389-399, 2002.

[12] N. Laosiripojana and S. J. Assabumrungrat, "Catalytic steam reforming of methane, methanol, and ethanol over Ni/YSZ: The possible use of these fuels in internal reforming SOFC," Power Sources, vol. 163, pp. 943-951, 2007.

[13] V. R. Choudhary and K. C. Mondal. " $\mathrm{CO}_{2}$ reforming of methane combined with steam reforming or partial oxidation of methane to syngas over $\mathrm{NdCoO}_{3}$ perovskite-type mixed metal-oxide catalyst," Applied Energy, vol. 83, issue 9, pp. 1024-1032, 2006.

[14] T. B. Schädel, M. Duisberg, and O. Deutschmann, "Steam reforming of methane, ethane, propane, butane, and natural gas over a rhodium-based catalyst," Catal. Today, vol. 142, pp. 42-51, 2009.

[15] N. V. Parizotto, K. O. Rocha, S. Damyanova et al., "Alumina-supported Ni catalysts modified with silver for the steam reforming of methane: Effect of Ag on the control of coke formation," Appl. Catal. A: Gen., vol. 330, pp. 12-22, 2007.

[16] M. Nurunnabi, K. Fujimoto, K. Suzuki et al., "Promoting effect of noble metals addition on activity and resistance to carbon deposition in oxidative steam reforming of methane over $\mathrm{NiO}-\mathrm{MgO}$ solid solution," Catal. Commun., vol. 7, pp. 73-78, 2006.

[17] L. V. Mattos, E. R. de Oliveira, P. D. Resende, F. B. Noronha, and F. B Passos, "Partial oxidation of methane on $\mathrm{Pt} / \mathrm{Ce}-\mathrm{ZrO}_{2}$ catalysts," Catal. Today, vol. 77, pp. 245-256, 2002.

[18] A. Al-Musa, S. Shabunya, V. Martynenko, S. Al-Mayman, V. Kalinin, M. Al-Juhani, and K. Al-Enazy, "Partial oxidation of methane in an adiabatic-type catalytic reactor," J. Power Sources, vol. 246, pp. 473-481, 2014.

[19] Mansouri, O. Benlounes, C. Rabia et al., "Partial oxidation of methane over modified Keggin-type poly oxotungstates," J. Mol. Catal. A: Chemical, vol. 379, pp. 255-262, 2013.

[20] R. Liu, M. Yang, C. Huang, W. Weng, and H. Wan, "Partial oxidation of methane to syngas over mesoporous $\mathrm{Co}-\mathrm{Al}_{2} \mathrm{O}_{3}$ catalysts," Chinese Journal of Catalysis, vol. 34, pp. 146-151, 2013.

[21] S. Boullosa-Eiras, T. Zhao, E. Vanhaecke, D. Chen, and A. Holmen, "Partial oxidation of methane to synthesis gas on $\mathrm{Rh} / \mathrm{Zr}_{\mathrm{x}} \mathrm{Ce}_{1-\mathrm{x}} \mathrm{O}_{2}-\mathrm{Al}_{2} \mathrm{O}_{3}$," Catal. Today, vol. 178, pp. 12-24, 2011.

[22] J. Hu, Ch. Yu, Y. Bi et al., "Preparation and characterization of $\mathrm{Ni} / \mathrm{CeO}_{2}-\mathrm{SiO}_{2}$ catalysts and their performance in catalytic partial oxidation of methane to syngas," Chinese Journal of Catalysis, vol. 35, pp. 8-20, 2014.

[23] L. D. Vellaa, J. A. Villoria, S. Specchiaa et al., "Catalytic partial oxidation of $\mathrm{CH}_{4}$ with Nickel-Lanthanum-based catalysts," Catal. Today, vol. 171, pp. 84-96, 2011. 
[24] J. H. Lunsford, "Catalytic conversion of methane to more useful chemicals and fuels: a challenge for the 21 st century," Catal. Today, vol. 63, pp. 165-174, 2000.

[25] Y. Wang and $\mathrm{Y}$. Ohtsuka, "CaO-ZnO Catalyst for selective conversion of methane to $\mathrm{C}_{2}$ hydrocarbons using carbon dioxide as the oxidant," $J$. Catal., vol. 92, pp. 252-255, 2000.

[26] H. Y. Wang and E. Ruckenstein, "Carbon dioxide reforming of methane to synthesis gas over supported rhodium catalysts: The effect of support," Appl. Catal. A: Gen. vol. 204, pp. 143-152, 2000.

[27] V. Havran, P. M. Duduković, and S. Lo. Cynthia, "Conversion of methane and carbon dioxide to higher value products," Ind. Eng. Chem Res. vol. 50, pp. 7089-7100, 2011.

[28] M. Fan, A. Z. Abdullah, and S. Bhatia, "Catalytic technology for carbon dioxide reforming of methane to synthesis gas," Chem. Cat. Chem., vol. 1, pp. 92-208, 2009.

[29] A. G. Dedov, A. S. Loktev, I. I. Moiseev, A. Aboukais, J. F. Lamonier, and I. N. Filimonov, "Oxidative coupling of methane catalyzed by rare earth oxides: Unexpected synergistic effect of the oxide mixtures," Appl. Catal. A: Gen. vol. 245, pp. 209-220, 2003.

[30] L. Y. Chen, L. W. Lin, Z. S. Xu, X. S. Li, and T. Zhang, "Dehydro -oligomerization of Methane to Ethylene and Aromatics over Molybdenum/HZSM-5 Catalyst," J. Catal, vol. 157, pp. 190-200, 1995.

[31] A. Corma and H. García, "Lewis acids as catalysts in oxidation reactions: From homogeneous to heterogeneous systems," Chem. Rev, vol.102, pp. 3837-3892, 2002.

[32] A. E. Castro Luna and M. E. Iriarte, "A continuous catalytic system for biodiesel production," Appl. Catal. A: Gen. vol. 343, pp. 10-15, 2008

[33] A. A. Adamu, V. R. Kyslov, and V. V. Skudin, "Mathematical balance dry reforming of methane in the membrane reactor," Successes in Chemistry and Chemical Technology, vol. 28, no. 10, pp. 7-20, 2014 (in Russian).

[34] M. Lallemand, A. Finiels, F. Fajula, and Vasile Hulea, "Catalytic oligomerization of ethylene over Ni-containing dealuminated Y zeolites," Appl. Catal. A: Gen., vol. 301, pp. 196-201, 2006.

[35] Zh. Si, D. Weng, X. Wu, J. Yang, and Bin Wang, "Modifications of $\mathrm{CeO}_{2}-\mathrm{ZrO}_{2}$ solid solutions by nickel and sulfate as catalysts for $\mathrm{NO}$ reduction with ammonia in excess $\mathrm{O}_{2}$," Catal. Commun., vol. 11, pp. 1045-1048, 2010

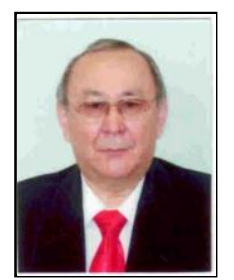

Dossumov Kusman was born in Semipalatinsk, Republic of Kazakstan on February 27, 1950. Since 2000 , he has been a professor of chemistry, Almaty, Kazakhstan. In 1996, he got the doctor degree diploma, in catalysis, IOCE AS RK, Almaty, Kazakhstan. In 1972, he got the high education diploma Kaz SU, chemistry, Almaty, Kazakhstan. He was the deputy director of CHMA al-Farabi Kaz NU, Almaty, Kazakhstan during 2007-2010. He was the general director of D. V. Sokolsky Institute of Organic Catalysis \& Electrochemistry (IOCE) Ministry of Education \& Science (MES) Republic of Kazakstan (RK), during 1995-2007. He was the deputy director of D. V. Sokolsky IOCE MES RK during 1972-1995. He is a leading Sci researcher, senior Sci researcher, junior Sci researcher, engineer of IOCE NAS RK. His current research interests are catalysis, petrochemistry, ecology.

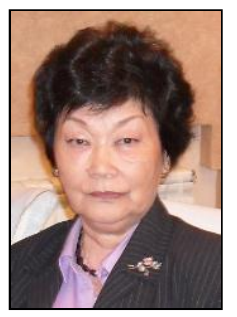

Churina Dina Khamidovna was born in Alma-Ata on November 17, 1943. In 1985, she got the leading researcher diploma, Moscow, SU. In 1973, she got the diploma of candidate of chemical sci, catalysis, electrochemistry, Almaty, Kazakhstan. In 1965, she got the high education diploma Kaz SU, chemistry, catalysis, Almaty, Kazakhstan. And she is now a senior researcher in CHMA al-Farabi Kaz NU, Almaty, Kazakhstan since 2011. During 1978-2010, she was a secretary of scientific affairs IOCE NAS RK, Almaty, Kazakhstan. During 1965-1978, she was a Sci researcher, engineer IOCE AS RK, Almaty, Kazakhstan. Her current research interests are catalysis, electrochemistry, ecology.

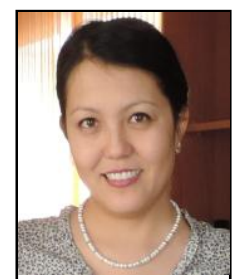

Yergaziyeva Gaukhar Yergaziyevna was born in Alma-Ata on September 17, 1979. In 2011, she got the diploma of candidate of chemical sci, catalysis, Almaty, Kazakhstan. In 2002, she got the diploma of master from KazNU al-Farabi, Almaty, Kazakhstan. In 2000, she got the diploma of bachelor KazNU al-Farabi, Almaty, Kazakhstan. In 2013, she was a leading Sci researcher of Institute of Combustion Problems. During 2003-2011, she was a senior Sci researcher, junior Sci researcher, engineer of IOCE NAS RK. Her current research interests are catalysis, petrochemistry, ecology.

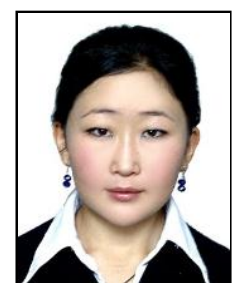

Myltykbayeva Laura Kadenovna was born in Semipalatinsk, Republic of Kazakstan on May 11, 1988. In 2012, she got diploma of master from Abay KazNPU, Almaty, Kazakhstan. And she is a PhD student at al-Farabi Kaz NU, Almaty, Kazakhstan since 2012. She is a junior researcher in CHMA al-Farabi Kaz NU, Almaty, Kazakhstan. In 2014, she had an internship in Japan for 4 month. Her current and previous research interests include catalysis,

ecology. 